\title{
Achieving Post-Acquisition Success: The Role of Corporate Entrepreneurship
}

\author{
Neil Thomson and Peter McNamara
}

Corporate entrepreneurship can play a central role in the integration of mergers and acquisitions. This paper describes a study spanning seven years for six mergers and acquisitions that involved UK, US and Swedish acquisitions of East German firms. The authors used the respective strengths of corporate entrepreneurship to predict the likely success or failure of each M\&A, with very accurate results when they revisited the companies in 2001. The authors draw further lessons from the study by linking corporate entrepreneurship to the learning organisation and providing practical lessons for managers. (c) 2002 Elsevier Science Ltd. All rights reserved

\section{Introduction}

Many challenges face companies in the wake of a takeover. For the acquirer, it must successfully integrate its new asset and seek to reap benefits from its outlay. For the company that has been taken over, it must find its place in the new corporate culture yet not lose its confidence amid the shake-up. We argue that these and other problems can be addressed and resolved through the development of corporate entrepreneurship. Corporate entrepreneurial activities help the acquisition to add value to the corporation as a whole. To explore this point we undertook six case studies of foreign acquisitions of firms in East Germany. Our aim is to illustrate, through this dataset, that corporate entrepreneurship plays an important role in the success of an acquisition. To explore these issues we collected data on the six acquisitions over the period 1995-1996 and then observed the success or failure of the acquisition in the summer of 2001.

Acquisitions that are successfully integrated into the new organisation will not be divested, while acquisitions that cannot
Dr Neil Thomson is Professor of International Business

Management at the Nürnberg University of Applied Sciences, Bahnhofstrasse 87, 90402 Nürnberg, Germany. E-mail: neil.thomson@fh-nuernberg.de. Dr Peter Mc Namara is a College Lecturer at the Department of Business Administration, University College Dublin, John Henry Newman Building, Belfield, Dublin 4, Ireland. E-mail: peter.mcnamara@ucd.ie. 
integrate will be divested in the years after acquisition. We find that firms which created an environment that fostered corporate entrepreneurship soon after acquisition were the firms that remained within the acquirer's portfolio into the 21st century. Those that did not foster corporate entrepreneurship in the years following acquisition had been divested by 2001 . Two of the firms had a medium level of corporate entrepreneurship and in these cases the hostility of the business environment played a moderating role in portfolio divestment.

Theoretically this paper is unusual in that we highlight the role of corporate entrepreneurship in the post-acquisition (integration) phase of acquired firms, rather than focusing upon corporate entrepreneurship in the context of organic growth by mature organisations. We define and explore the concept of corporate entrepreneurship and by using contrasting case studies, amongst other methods, we isolate and study its constituents. These constituents are investigated via surrogate variables, which are used to predict the future success of M\&As. All the internal constituents of corporate entrepreneurship can be influenced, to differing degrees, by management, so emphasising that the successful integration of M\&As via corporate entrepreneurship is a practical managerial goal. We recognise that the internal development of an organisation can potentially be dominated by events outside the firm and so we also employ a measure of external market pressures.

\section{The generic problem}

In addressing the scope of our research, we drew partially upon the work of Charles Hampden-Turner. ${ }^{1} \mathrm{He}$ emphasised the importance of seeing managerial problems as dilemmas to be resolved rather than decisions to be made. A dilemma is the juxtaposition of perceived opposites, for example, simultaneous pursuit of economics of scale and economies of flexibility. The management of the acquiring corporation is faced with an initial dilemma, namely how to integrate efficiently the acquired firm into the systems of the wider corporation without destroying distinctive features of the acquired firm that will generate new wealth for the corporation. Efficiency of integration may well imply suppression of the identity and distinctive behaviours of the acquired firm in favour of rapid integration into the structures of the wider corporation. Assuming that a market price has been paid, then wealth is only created if the acquisition adds something distinctive to the corporation. New wealth can be created through novel combinations of distinctive knowledge, resources and capabilities. Can these additions be preserved or created by the acquisition when integration efficiency is optimised? The difficulty of this generic dilemma is emphasised by the 44 per cent failure rate experienced by new acquisitions. ${ }^{2}$ Previous studies have highlighted the importance of managing the process of postacquisition integration. ${ }^{3}$ We explore an important, but over- 
looked dimension of post-acquisition integration, namely corporate entrepreneurship.

We argue that corporate entrepreneurial activities can play an important role in the identification of valuable distinctive knowledge and capabilities of the acquired firm and their integration into the new corporation. We view the constituents of corporate entrepreneurship as the cement that binds the two diverse communities brought together by a takeover. The success of posttakeover integration is reflected in the ability to address a second dilemma. All the sample firms were faced with the choice of reducing costs by laying off workers, or keeping employees to gain the positive benefits of organisational slack. The second dilemma is therefore, save costs today through redundancies or gain potential benefit in the future through innovative redeployment of underemployed human resources. The common element in solving each dilemma is corporate entrepreneurship.

\section{Definition of corporate entrepreneurship}

The concept of corporate entrepreneurship received much attention in academic writing in the late 1980s and early 1990s. ${ }^{4}$ The goal of corporate entrepreneurship is for large organisations to recreate the benefits of flexibility and innovation, often associated with small firms, in a large firm setting. Our sample firms reflect this scenario. Corporate entrepreneurship involves teams within a firm, led by intrapreneurs or corporate champions who promote entrepreneurial behaviour inside large organisations, proactively engaging in risky projects that seek to create new, innovative, administrative procedures, products and services that facilitate organisational renewal and growth. ${ }^{5}$ Corporate entrepreneurial activities act as a counter-balance against the natural tendency of organisations towards inertia and creation of core rigidities. It has long been argued by corporate entrepreneurship studies that there is a positive relationship between corporate entrepreneurship and organisational performance. ${ }^{6}$

The factors making up corporate entrepreneurship (see column 1, Table 1) are taken from a key study on corporate entrepreneurship, namely Baden-Fuller and Stopford. ${ }^{7}$ These factors are both complex and broad. In Table 1 (column 2) we offer measures for these general concepts, focusing on narrower and more directly observable dimensions. We do not claim that these measures capture the full breadth of each factor, but argue that they act as useful proxies, or surrogates for them, enabling interesting insights into the more general concept of corporate entrepreneurship. We view these surrogates as an observable bridge for managers between the academic basis of corporate entrepreneurship and practical, measurable management challenges.

\section{Justification of corporate entrepreneurship surrogates}

The key constituents of corporate entrepreneurship proposed by Baden-Fuller and Stopford are: learning capabilities, team orien-
Corporate

entrepreneurial

activities can identify

valuable knowledge

and capabilities 


\begin{tabular}{|c|c|c|}
\hline $\begin{array}{l}\text { Corporate } \\
\text { entrepreneurship- } \\
\text { constituents }\end{array}$ & $\begin{array}{l}\text { Corporate } \\
\text { entrepreneurship-- } \\
\text { surrogates in this } \\
\text { paper. }\end{array}$ & $\begin{array}{l}\text { Measurement of } \\
\text { surrogates (further } \\
\text { details provided in } \\
\text { Appendix A) }\end{array}$ \\
\hline Learning capability & $\begin{array}{l}\text { - Presence and } \\
\text { integration of diverse } \\
\text { perspectives. }\end{array}$ & $\begin{array}{l}\text { - Continuum from } \\
\text { no integration of } \\
\text { diverse perspectives to } \\
\text { presence and } \\
\text { integration of diverse } \\
\text { perspectives }\end{array}$ \\
\hline Team orientation & - Shared language. & $\begin{array}{l}\text { - Absence or } \\
\text { presence of a shared } \\
\text { technical and } \\
\text { managerial language }\end{array}$ \\
\hline \multirow{3}{*}{ Experimentation } & $\begin{array}{l}\text { - Degree of } \\
\text { information withholding } \\
\text { by team members. }\end{array}$ & $\begin{array}{l}\text { - Continuum from } \\
\text { no free exchange of } \\
\text { information to free } \\
\text { exchange of } \\
\text { information }\end{array}$ \\
\hline & $\begin{array}{l}\text { - Slack resources } \\
\text { available for } \\
\text { experiments. }\end{array}$ & $\begin{array}{l}\text { - Continuum from } \\
\text { no slack resources to } \\
\text { much slack present in } \\
\text { system }\end{array}$ \\
\hline & $\begin{array}{l}\text { - Culture supportive of } \\
\text { experimentation. }\end{array}$ & $\begin{array}{l}\text { - Continuum from } \\
\text { active opposition to } \\
\text { active support of } \\
\text { experimentation with } \\
\text { current business } \\
\text { practices }\end{array}$ \\
\hline Ambition & $\begin{array}{l}\text { - Aspirations beyond } \\
\text { current resources. }\end{array}$ & $\begin{array}{l}\text { - Continuum from } \\
\text { low to high } \\
\text { aspirations }\end{array}$ \\
\hline
\end{tabular}

tation, experimentation and ambition. A fifth constituent is resolution of dilemmas. Dilemma resolution can be progressed via a process of incremental experimentation; thus this is subsumed into the concept of experimentation in our study. We have measured the concept of acquisition success as the survival, or nondivestment, of the East German firm by its western acquirer from takeover up to 2001. Non-divestment, or survival within the portfolio of the acquirer, of the East German firm was a key goal of the state's privatisation process and has been used as a metric of success in prior studies. ${ }^{8}$ The rationale for selection of surrogates for each of the four constituents of corporate entrepreneurship is provided below (and summarised in Table 1). Further discussion of each of these constituents of corporate entrepreneurship and illustration from our dataset is provided in the data analysis section of this paper. 


\section{Learning capability and team orientation}

According to Grant and March, ${ }^{9}$ because organisations are inanimate constructs they do not learn themselves: rather knowledge creation is an individual activity. The key role of a firm in the process of knowledge creation is to bring together the diversity of ideas and perspectives of individuals and harness that creative energy in team activities. Teams of individuals experiment with combinations of ideas to create innovative processes and products that no one individual could have conceptualised or practically produced alone. Organisational learning, and by extension corporate entrepreneurship, is a team activity. For entrepreneurial teams to operate successfully they need two basic building blocks: a shared language to communicate their ideas and sufficient trust both of each other and the firm, to share their insights. Nonaka et al. ${ }^{10}$ have argued that the process of innovation by teams requires dialogue between team members and conversations across functional boundaries to facilitate productive exploitation of new product and process concepts. Such dialogue requires a common basic language and perspective, which acts as a foundation upon which teams can productively share ideas and create new products and services. Constructive dialogue requires that team members have sufficient trust of each other and the organisation that they can share their most valuable ideas without fear of alienation or personal loss. A clear signal that team orientation has broken down is when individuals within a team hoard important information and are unwilling to pool it with others in the team as part of the process of experimentation. ${ }^{11}$ A lack of team orientation implies that corporate entrepreneurial activities will fail.

\section{Experimentation and ambition}

In his review of the literature on organisational learning, Huber observed that at the heart of organisational learning lies experimentation: ${ }^{12}$ a novel combination of resources by teams to create new products and processes. Experimentation is not, however, possible without slack resources that can be recombined. Even where slack resources are available for redeployment or reconfiguration it requires the will of management and staff to make experiments happen. Thus a critical aspect of experimentation is whether or not there exists a culture of experimentation within the firm itself. Hitt et al. ${ }^{13}$ have observed that corporate entrepreneurship teams can be formally created by a firm; however, without the active support of experimentation by management and a desire to experiment on behalf of the team, important new products and processes will not be generated. Thus both availability of slack resources and a culture of experimentation are the surrogates we apply to the constituent experimentation.

The surrogate for ambition is a strategic intent to expand the firm through creation of new products and/or movement into new geographic markets. Baden-Fuller and Stopford observed that ambition (or aspirations) 'capture the goal of progress and

\section{Organisational}

learning is a team

activity 
Cross-cultural

differences represent

an opportunity for

corporate

entrepreneurs continuous improvement by finding better combinations of resources'.$^{14}$ To successfully expand through new product development these firms would need to innovatively reconfigure their current resources. Equally, to expand into new geographic markets they would need to redeploy resources and retrain employees to service these markets. Such strategic intentions require finding better combinations of resources and are therefore good surrogates of the constituent ambition.

Corporate entrepreneurship does not enjoy a standard or commonly agreed definition. ${ }^{15}$ Three types of corporate entrepreneurship appear in literature, namely, corporate venturing, transformation of existing businesses, and changing of industry rules. ${ }^{16}$ Like Baden-Fuller and Stopford, we concentrate upon the second, or transformation type, as our focus is upon acquisitions of firms in a rapidly transforming economy all of which were renewal situations. Transformational corporate entrepreneurship can be viewed as entailing the reallocation of existing resources and the creation of new capabilities with the goal of organisational renewal and improved economic performance. ${ }^{17}$ Such transformation requires the effort of teams as opposed to the isolated efforts of a few individuals.

\section{Methodology}

Six mergers and acquisitions (M\&As) involving the purchase of an East German firm by non-German firms were researched, using 36 in-depth interviews. Much of East Germany's industry was privatised by a specially created authority, the Treuhandanstalt (THA), in the years following the fall of the Berlin Wall. Empirically this paper is unusual in that although the vast majority of acquisitions of East German firms from the THA were by West German companies, we studied the acquisition of six East German companies by non-German firms. Foreign acquisitions ensure even greater than normal potential exposure to upheaval, as differing national cultures are added to the already heavy mixture of influences on integration and change. Cross-cultural differences do, however, represent an opportunity for corporate entrepreneurs. National variations in culture, administrative processes and capabilities of firms offer the potential to create new and unique organisational capabilities that can form the basis for organisational renewal and improved performance.

Although we made a careful choice regarding size of firms and sectors, the selection of actual firms within these sectors relied upon those who granted interview access to their management and employees. Interviewees ranged from senior to junior management within the East German firms. Based on these interviews the two most extreme firms were developed into cases to be used as contrasts. Details about the sample firms are summarised in Table 2. Please note that throughout this paper company and interviewee names are not reported as all requested that their identities remain confidential. All interviews were translated into 
Table 2. Details of M\&As researched

\begin{tabular}{|c|c|c|c|c|c|}
\hline $\begin{array}{l}1 \\
\text { Data source } \\
\text { and location }\end{array}$ & $\begin{array}{l}2 \\
\text { Acquirer } \\
\text { nationality }\end{array}$ & $\begin{array}{l}3 \\
\text { Size of } \\
\text { M\&A to } \\
\text { total ops. }\end{array}$ & $\begin{array}{l}4 \\
\text { Details of } \\
\text { ownership }\end{array}$ & $\begin{array}{l}5 \\
\text { Business sector }\end{array}$ & $\begin{array}{l}6 \\
\text { Number of } \\
\text { employees }\end{array}$ \\
\hline $\begin{array}{l}\text { Company A: } \\
\text { Saxony and } \\
\text { Saxon-Anhalt }\end{array}$ & US and UK & $\begin{array}{l}0-5 \text { per } \\
\text { cent }\end{array}$ & $\begin{array}{l}100 \text { per cent } \\
\text { acquisition }\end{array}$ & Utilities & 2100 \\
\hline $\begin{array}{l}\text { Company B: } \\
\text { Berlin-East }\end{array}$ & UK & $\begin{array}{l}0-5 \text { per } \\
\text { cent }\end{array}$ & $\begin{array}{l}100 \text { per cent } \\
\text { acquisition }\end{array}$ & $\begin{array}{l}\text { Heavy electrical } \\
\text { equipment }\end{array}$ & 400 \\
\hline $\begin{array}{l}\text { Company C: } \\
\text { Saxon-Anhalt }\end{array}$ & Sweden and UK & $\begin{array}{l}0-5 \text { per } \\
\text { cent }\end{array}$ & $\begin{array}{l}\text { East German CEO } \\
\text { retained small } \\
\text { shareholding }\end{array}$ & $\begin{array}{l}\text { Water/water } \\
\text { purification systems }\end{array}$ & 50 \\
\hline $\begin{array}{l}\text { Company D: } \\
\text { Saxony }\end{array}$ & UK & $\begin{array}{l}0-5 \text { per } \\
\text { cent }\end{array}$ & $\begin{array}{l}30 \% \text { of shares held } \\
\text { by East German } \\
\text { managers }\end{array}$ & $\begin{array}{l}\text { Architectural and } \\
\text { engineering services }\end{array}$ & 240 \\
\hline $\begin{array}{l}\text { Company E: All } \\
\text { East Germany }\end{array}$ & UK & $\begin{array}{l}0-5 \text { per } \\
\text { cent }\end{array}$ & $\begin{array}{l}100 \% \text { owned West } \\
\text { German subsidiary } \\
\text { expansion }\end{array}$ & Agricultural industry & 20 \\
\hline $\begin{array}{l}\text { Company F: } \\
\text { Saxony }\end{array}$ & US & 50 per cent & $\begin{array}{l}25 \% \text { of shares stayed } \\
\text { with THA }\end{array}$ & Specialist chemicals & 100 \\
\hline
\end{tabular}

English. The bulk of the data collection took place in 1995-1996, although additional data was collected in 2001, allowing comparison of our predictions with actual outcomes. As noted earlier, details of the measurement of the constituents of corporate entrepreneurship are provided in Table 1.

Appendix A contains the details of how we measured the surrogates of corporate entrepreneurship and the success or failure of an M\&A.

\section{Data analysis}

Where a corporate entrepreneurial environment is developed then over time a stream of innovations in terms of organisational capabilities (novel and effective organisational systems, processes, routines) and products will emerge from the acquired firm. The greater the presence of a given measure of the underlying constituent of corporate entrepreneurship (as detailed in Table 1), then the greater the strength of the corporate entrepreneurial environment. By extension we predict that the stronger the presence of the constituents of corporate entrepreneurship inside a given firm, then the more likely it is to be successful at the generation of new capabilities or products. Thus we detail the strength of each of these constituents in the sample firms and we use this analysis as a prediction of long-term ability of the acquired firm to survive. 


\section{Measurement of the strength of the constituents of corporate entrepreneurship}

Where managers can identify the key factors, or building blocks, of corporate entrepreneurship in a new acquisition, then an exciting opportunity exists to nurture the seeds of corporate entrepreneurship in the early post-acquisition stage. Once these factors are isolated, their importance can be determined and managers can influence them.

By analysing our six case companies we were able to see that the factors of corporate entrepreneurship were relevant to the experience of firms acquired by western partners in the old East Germany. As already mentioned, these factors are quite broad concepts that are difficult to observe objectively as a whole and so we used surrogates to evaluate them. These surrogates capture an important ingredient of each of the more general factors of corporate entrepreneurship. An assessment of the presence and importance of the constituents of corporate entrepreneurship to each of the sample firms is summarised in Table 3.

We will now discuss each of the four constituents of corporate entrepreneurship as outlined in Table 1 in the context of the six M\&As. We will combine a theoretical understanding of each of these factors with findings from our case studies. We will also analyse the business environment that each of these firms operated within, assessing the extent to which this environment was positive or negative. We will then discuss the relationship between corporate entrepreneurship, acquisition survival and the moderating effect of a positive or negative business environment. This will enable us to make predictions of the likely long-term success or failure of each of these M\&As from the perspective of 1996-1997. In subsequent sections of the paper we will compare our predictions with the data on the survival of the firms as collected in 2001. Such a comparison across time allows us to demonstrate whether or not the presence of corporate entrepreneurship is a robust predictor of survival.

\section{Learning capability_importance of diversity}

The creation of new organisational knowledge is strongly influenced by the interaction between individual knowledge and the firm's knowledge base. The firm's knowledge is embedded in its routines, culture, group behaviours and hierarchy. On average, the knowledge stored in these systems will be a more accurate reflection of reality than the individual's view. ${ }^{18}$ However, organisations are inanimate objects. It is only through the diversity of individuals' knowledge that the firm can change its view of the world and hence its capabilities. ${ }^{19}$ Diversity of individual knowledge bases may suggest novel combinations of the firm's current resources. The diversity that an M\&A brings can thus be an excellent vehicle for organisational learning.

Diversity can be injected into the firm by two means: the existence of organisational mavericks and personnel turnover. ${ }^{20}$ Mavericks are people who are slow to be indoctrinated by the organisational orthodoxy and thus challenge the current ways of 


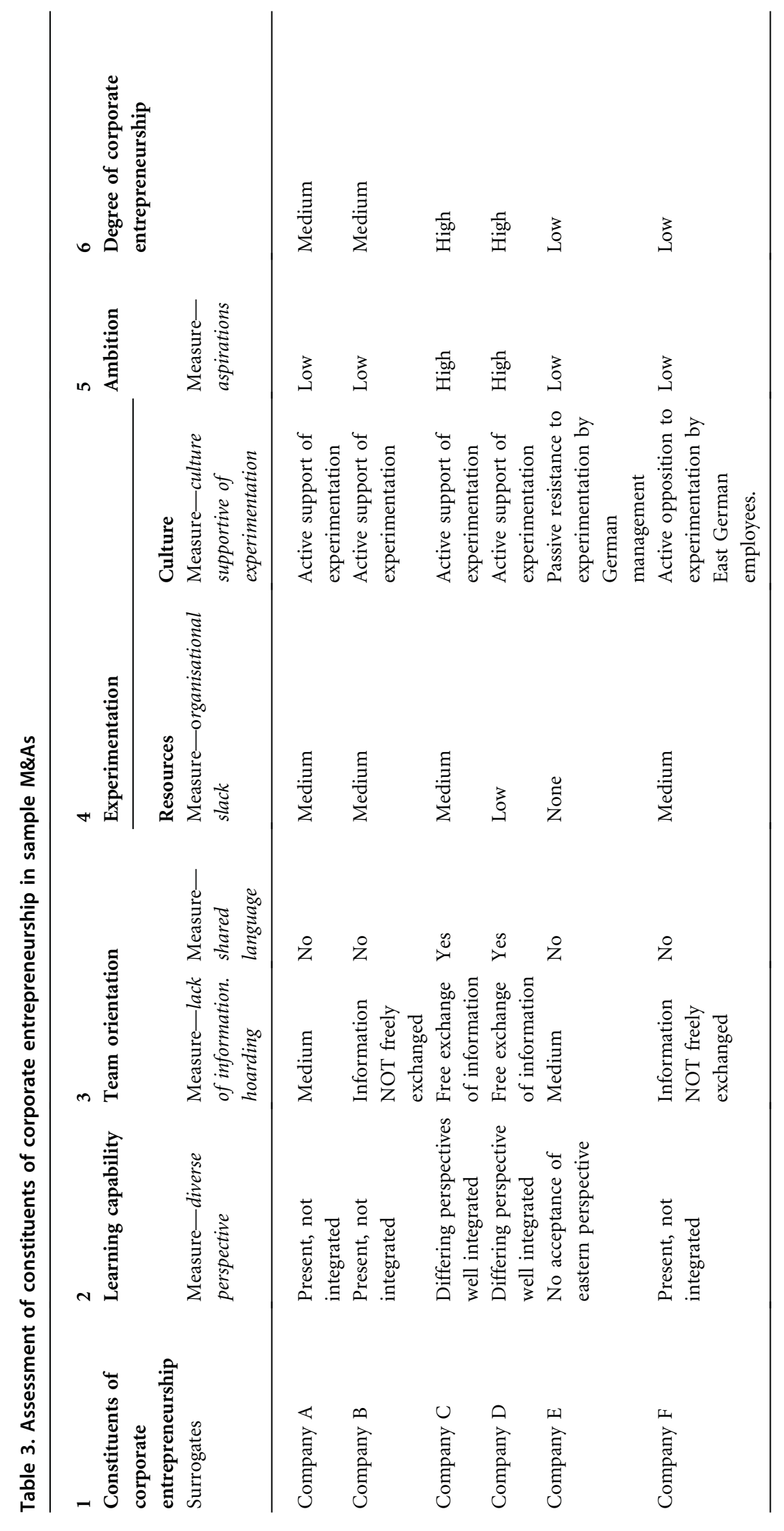


New personnel

question and

challenge the current

orthodoxy operation. While there is evidence in the case companies that such people were rare in pre-privatisation times, ironically they may have surfaced post-acquisition, where individuals resisted the pressure to accept capabilities imposed upon them from the western partner. In the case of Company $\mathrm{F}$ such resistance was negative, in that it did not prompt dialogue and integration of the best aspects of each firm's capabilities across the new firm. In this company eastern managers chose to hoard information, thus refusing to infuse the organisation with their insights and knowledge. While this was maverick behaviour, it was also destructive. In companies $\mathrm{C}$ and $\mathrm{D}$, where levels of diversity of perspectives were high, mavericks did exist but were embraced by the organisation as a whole (see Table 3 ). The reluctance of these firms to accept immediately the western partner's capabilities without adaptation spurred on the process of corporate entrepreneurship.

Complementing the role of mavericks in the process of knowledge and capability creation is personnel turnover. New personnel bring with them new ideas and their unfamiliarity with the firm's capabilities leads them to question and challenge the current orthodoxy. Personnel turnover was very high in our sample on two levels. The most important of these was the arrival of, usually a few, new people from the western partner at the senior management level. The other was the general turnover of employees in the restructuring of ex-combines, where in the majority of cases as many as 80 per cent of jobs were lost. In this latter situation, no new personnel were involved but the unfreezing effect of job uncertainty often led to less rigid mindsets.

This combination of high levels of personnel turnover and mavericks within the eastern firms produced an environment rich in creative tension. New personnel and mavericks brought insights into alternative ways of running the business, thus enabling the firm to envision new methods of working. The very fact that M\&As' formation is often accompanied by middle and top management turnover ${ }^{21}$ ensures change at the highest level. Our sample of East German M\&As often saw initially very high management turnover, due to the weeding-out of political appointees and older managers, usually occupying positions at the highest level. The managerial systems of the eastern firms prior to takeover promoted staff on the basis of politics and age, rather than merit. Such a managerial system stifles mavericks and personnel turnover and discourages differences. This posed a considerable challenge for the new management. One manager captured the profile of employees in Company E by observing that they were like civil servants and quite risk adverse, unwilling to experiment and change organisational systems. Instead they followed a strategy of keeping the firm strongly embedded within the old, moribund supplier-buyer network. He noted that:

"It was just important for us to have people with connections and also who were, to a certain extent, known to us 
through connections. We could probably be criticised for not having noticed beforehand that those in higher positions would not be the youngest. We weren't interested in age. Following on from that, we ended up with a bundle of people over 50 years of age, a high percentage of whom could not handle the change in their way of life. Specifically, the change from East German standards to the demands placed by a West German subsidiary of a British firm. What I mean here is commitment, motivation, goals, work methods etc." 22

\section{Team orientation}

In corporate entrepreneurial activities teams, rather than hierarchies, form the key to the creation of new managerial processes, which push the firm to invest in new, or more efficient methods of organisation and production, and innovative products and services..$^{23}$ As argued earlier, team orientation requires both shared language and lack of information hoarding by team members. Given the rigidity of the former hierarchies of East German industry, a key to the rejuvenation of this sample of firms was to encourage teams to be entrepreneurial, create new knowledge and insights about the direction of the firm, and thus refresh the firm in spite of the negative effects of conformity that hierarchy promotes. Team members will be unwilling to share information where trust between individuals or the firm is absent. Lack of trust has often been argued to be a central factor in inhibiting the successful operation of teams, ${ }^{24}$ in particular, for their ability to create new organisational knowledge and challenge the orthodoxy of hierarchy.

\section{Information hoarding}

There is a strong relationship between the existence of trust between team members and the absence of information hoarding. ${ }^{25}$ If the process of intermingling the incoming and existing company cultures is not carefully managed then communication breaks down, trust between functional groups and individuals within the firms is diminished and thus corporate entrepreneurial learning is impeded. This may in part be a response to a failure by the two parties to understand each other's differing perspectives. If understanding emerges then a key ingredient of team-based corporate entrepreneurship, namely trust, shared worldview and ability to communicate across disciplinary boundaries to develop inter-disciplinary products and services, can develop. If not, specialists may retreat into information hoarding or functional balkanisation as a strategy to maintain their employment, but to the detriment of team effectiveness. The most striking example of information hoarding and its detrimental impact upon corporate entrepreneurship in our sample occurred in Company F. One of the German managers noted that a culture of fear emerged where German employees worried about the security of their jobs and responded with knowledge hoarding. As she put it: 
A shared common

language is

important for cross-

functional teams
“...One keeps one's knowledge to oneself in order to somehow or other become indispensable. The fear of losing your job, that is always in the background. We are all at such an age that if we were to have to leave the firm we would find it almost impossible to get a new position and we've all got a long way to go to retirement...."

"I used to try and delegate my work, now I prefer to finish it myself."

These individuals and the teams within which they operated had deep reservoirs of technical knowledge which the new owners wished to access. However access was hindered by the German employees' fears, which resulted in high levels of information hoarding and an inability of teams to engage in corporate entrepreneurial activities. The German employees felt that they were going to be sold out. However, interviews with the western managers indicated that this was not the case and they believed that the German employees had a lot to offer and were willing to learn. Expectations were in this case acutely different and so the opportunity to develop synergistic learning never occurred.

\section{Common organisational language}

Creation of a shared language is essential for team members to have a high degree of involvement with each other in the conduct of entrepreneurial activities and also in the creation of the trust required for teams to undertake activities successfully. ${ }^{26} \mathrm{~A}$ shared common language is especially important in the context of crossfunctional teams, where communication failures triggered by the lack of a common language and shared perspective can lead to functional balkanisation and the breakdown of corporate entrepreneurship. This can impede the completion of important tasks such as new product development and launch. ${ }^{27}$ The development of a shared language is a key element of both successful acculturation and corporate entrepreneurship. The absence of both impedes post-acquisition success.

For example, in the case of Company B there was the physical language barrier of German and English. Company B only realised that their German colleagues did not speak English and that the British managers they sent to East Germany did not speak German, upon the arrival of several managers from the UK after the completion of the acquisition! The deeper element of common language is the establishment of a common technical language and frame of reference, from which cross-functional groups, within the old firms and across the new combined firm, can effectively communicate.

Within our sample of eastern firms, there were surprisingly rich opportunities for shared language both within and more importantly, across functional specialities. This enabled crossfunctional teams to combine efficiently, allowing relatively efficient application of current capabilities and routines in the very harsh economic climate of the former communist bloc. One 
of the most exciting synergistic opportunities for east/west M\&As was the opportunity to combine this expertise in the application of current operations with western firms' strength in knowledge creation and innovation while avoiding system-wide core rigidities (which plagued combines). However, we found from our sample that, due to the actions of the acquiring firms, this opportunity went largely unrealised.

Low personnel turnover, high slack (discussed below), coupled with high degrees of socialisation inside and outside of work, fostered a common language within and across functional teams. Such interaction is argued to be a key ingredient to successful corporate entrepreneurship. ${ }^{28}$ Some combines in the old East Germany employed whole towns, e.g. Leuna. There was a very high degree of social interaction between workmates compared with the average western firm. All this was likely to give the employees a relatively high degree of shared personal experiences, fostering transfer of tacit knowledge, coupled with a lower need to rely on relatively more inefficient explicit knowledge transfer mechanisms. Within the established group, the potential to apply current knowledge bases is likely to have been relatively high, given the right motivational elements. However, with teams now completely broken up and many new owners not recognising the need to develop a new intra-firm common language for knowledge to be accessed and employed efficiently, the opportunity to combine two unique knowledge bases may have passed.

\section{Experimentation-creating an environment of calculated risk taking}

\section{Availability of slack resources}

Organisational slack is 'the pool of resources in an organisation that is in excess of the minimum necessary to produce a given level of organisational output'. ${ }^{29}$ Many authors argue that slack plays a positive role in creating increased rates of learning by permitting higher levels of social interaction and thus facilitating the creation of new product or service offerings and innovative organisational capabilities. ${ }^{30}$ Through creative usage of slack resources, management can promote an environment in which flexibility in work practices and experimentation in the creation of new products or processes is encouraged. Slack also enables creation of information overlaps between workers, thus stimulating knowledge sharing and easing job rotation. Job rotation is an important activity insofar as it stimulates knowledge sharing, triggering new insights into how to design cross-functional information processes more efficiently. Additionally, job rotation also ensures that the firm is less exposed to the sudden departure of an employee who holds critical competitive knowledge.

Nohria and Gulati ${ }^{31}$ empirically showed that there is a clear inverse $U$ relationship between a firm's learning, performance and slack. Put simply, this relationship implies that there is an equilibrium level of slack that facilitates learning and perform- 
Job rotation insures

against the departure

of an employee who

holds critical

knowledge ance. Too much slack has a negative effect on performance as has too little. The referenced study found that the optimum level of slack was about 5 per cent.

The presence of slack in our sample companies is shown in column 4 of Table 3. Company D offers an insight into the role that slack resources play in experimentation. This company had departments that were 'heavy' in personnel. Rather than making cost savings in the short term through redundancies, the firm experimented with new, productive activities to which the skills of these employees could be applied. Company D invested in retraining some of the personnel, transferring them from the Berlin operation, where they were an excess resource, to an export offensive in Russia. This export offensive was a success, providing the firm with an increased share of the Russian market.

A vital task in the reduction of excess levels of slack is to identify what knowledge is tacitly stored inside the purchased unit and where that knowledge resides. Once this knowledge is identified, the firm needs to establish what is surplus to requirements, what could be shed and what strategies should the new firm develop to nurture valuable knowledge and transfer it across the old organisational boundaries, embedding it in the routines, hierarchy and culture of the new firm. Evidence in our sample indicates that western acquirers often viewed slack, or overlaps in employees' duties and knowledge, as completely surplus to requirements and hence engaged in hasty mass redundancies, but the experiences of Company D illustrate that slack resources can be internally redeployed to create wealth. Such hasty reduction in absorbed slack represents a missed opportunity to obtain synergy from M\&As.

\section{Culture of experimentation}

Firms that promote corporate entrepreneurship encourage teams to try out new ideas, to modify administrative procedures and explore new product possibilities. These experiments need not be large scale, nor need failure of a single experiment be viewed as failure by the team. The process of improvement builds on the experience gained from both successful and unsuccessful experimentation, providing insights into what works and what does not. An interviewee from Firm $\mathrm{C}$ explained that its new owners fostered a culture of experimentation, enabling it to explore the market for new, more efficient and effective supply relationships. Previously, project teams were not free to experiment with changes in sources of supply, due to the rigidity of the combine. The new management enabled one team to experiment with new sources of building supplies with the goal of improved efficiency in the supply chain. As he put it:

"I am no longer forced to use certain building materials; I can choose them freely together with the builder... Now I take decisions individually, wood, bricks, stone, etc."

Without the existence of some slack, experimentation could 
not take place. In the case of an M\&A, without the development of some level of common language by which partners across old organisational boundaries can communicate, experiments, which seek to integrate capabilities across the old firms will be doomed to failure. With information hoarding, experimentation will not flourish. Finally, without diverse perspectives, experiments will generate little new insights. Thus experiments act as the lens through which some of the other constituents of corporate entrepreneurship - namely, organisational slack, diverse perspectives, lack of information hoarding and common languagecombine to add value in the form of learning which creates new or integrates old capabilities.

In the case of our sample firms, the new western owners had the freedom to introduce experiments as the East German operation was usually small in relation to the overall group size. Table 2 shows the relative size of the M\&As in the sample and with the exception of Company $\mathrm{F}$, all were insignificant in terms of comparative size to the combined group. The real return emanates from developing techniques to surface hidden capabilities in East Germany and then, if they prove successful, to export them to other countries or regions. If the new capabilities that arise from experimentation prove to be less effective than methods that existed previously, then the negative impact can be either reversed, or limited to the periphery of the new firm in East Germany. This process of experimentation is quintessentially about the willingness of corporate entrepreneurs to take measured risks, where benefits can be leveraged across the organisation, while downside risk is carefully managed.

Developing and nurturing hidden capabilities takes time. The opportunity cost of this time is slower implementation of staff pruning measures. The lower the fixation on instant financial returns, the more leeway to experiment is available. Company $\mathrm{F}$ provides a classic example of lack of ability to experiment. The aforementioned large size of the East German operation, plus the insistence of the THA (who retained shares and seats on the board) that no experiments could take place, led to an impasse and eventual failure. Companies $\mathrm{C}$ and $\mathrm{D}$ seemed to be left alone, with the rate of return on the investment being the only interference from HQ. Isolation allows experimentation but has an inherent danger that the results may not be of use to the whole group.

\section{Ambition-aspirations beyond current resources}

Hamel and Prahalad's idea of stretch and leverage resonates within the concept of corporate entrepreneurship. ${ }^{32}$ Stretch is a mismatch between (current) resources and aspirations. In other words, if a firm wants to expand quickly, reduce costs dramatically, upgrade quality substantially then this could be difficult given current resource levels and usage. The current resources need to be stretched to achieve ambitious goals. Resource leverage seeks to do just this, to get the most out of current resources, i.e. 'a bigger bang for the buck'. Leverage occurs by reassigning 
the resources in a manner so that they more tightly fit the ambitious output goals. A stark contrast with the other source of resource productivity, downsizing to become leaner, 'reducing the buck paid for the bang'.

We contend that the cut or stretch options are not either/or alternatives. Certainly in all our sample companies cutting took place. Firm $\mathrm{E}$ was the one exception because here the acquisition acquired only a shell company in East Germany and expanded it as an add-on to the West German subsidiary. Cutting as a strategy is hardly surprising given the horrendous levels (more than 80 per cent) of over-manning in East German industry. However, those sample firms we found to be more successfully shaping their own future-Companies $\mathrm{C}$ and $\mathrm{D}$-were actively throttling up their aspirations. They were attacking new market sectors and geographically expanding. The other firms were not increasing their product offerings nor extending their markets.

\section{Corporate entrepreneurship and the competitive environment}

The level of environmental turbulence that a firm faces may be a moderating factor between corporate entrepreneurship and survival. Where the environment is benign then greater levels of corporate entrepreneurship should lead to greater success. In the face of a very turbulent, negative, environment the innovative activities of corporate entrepreneurship may not be sufficient to guarantee survival. The constituents of corporate entrepreneurship discussed above do not exist in a vacuum. We can assess the existence of corporate entrepreneurship by gauging the presence or absence of its constituents. However, certain sample companies (A and B) as well as our successful contrast case (D) exhibited medium to high corporate entrepreneurship but according to management were still having problems making profits. The reason being that environmental market forces were offsetting the positive internal learning gains. These firms were surviving in 1996, but were not all profitable.

\section{Variables in the competitive environment}

An assessment of the existence of a 'Positive/Negative Business Environment' is important because the six companies were all subject to the macro level economic effects experienced by the post-wall East German economy. However, some were operating in markets protected from the general collapse in demand. Company A enjoyed a utility monopoly. Companies C and D faced a moderately hostile environment, though they did benefit in the early days after their purchase from the short, reunification construction boom. Company $\mathrm{F}$ had a complex product that was difficult for rivals to imitate and competed within a stable market in terms of demand. Both Companies B and E faced very hostile environments with dramatic competitive pressures, as well as plummeting demand. Weightings were given to each of the six companies' environments, by using Porter's five competitive 
forces. ${ }^{33}$ The analysis is summarised in Table 4. It is interesting to note that our contrast company (Company F) had probably the second most benevolent market conditions but as we shall see, due to internal factors, could not translate this into corporate success.

A summary (Table 5) shows: the existence of corporate entrepreneurship, the type of business environment and an assessment of present success of the various firms. In column 4, based on the research data obtained in 1996, we advanced our

Table 4. Assessment of business environment using Porter's five forces model

\begin{tabular}{|c|c|c|c|c|c|c|}
\hline 1 & $2^{i}$ & $3^{i}$ & $4^{\mathrm{i}}$ & $5^{i}$ & $6^{i}$ & $7^{\mathrm{ii}}$ \\
\hline Company & $\begin{array}{l}\text { Threat of new } \\
\text { entrants }\end{array}$ & $\begin{array}{l}\text { Buyers } \\
\text { bargaining } \\
\text { power }\end{array}$ & $\begin{array}{l}\text { Threat } \\
\text { from } \\
\text { substitutes }\end{array}$ & $\begin{array}{l}\text { Suppliers } \\
\text { bargaining } \\
\text { power }\end{array}$ & $\begin{array}{l}\text { Rivalry amongst } \\
\text { existing } \\
\text { competition }\end{array}$ & $\begin{array}{l}\text { Type of } \\
\text { business } \\
\text { environment } \\
+ \text { or - }\end{array}$ \\
\hline \multirow[t]{2}{*}{ A } & $\begin{array}{l}\text { Low (legally } \\
\text { sealed off } \\
\text { market) }\end{array}$ & $\begin{array}{l}\text { Low (isolated } \\
\text { consumers, Gov. } \\
\text { price control) }\end{array}$ & $\begin{array}{l}\text { Low (Some } \\
\text { gas in } \\
\text { heating) }\end{array}$ & $\begin{array}{l}\text { Low (Company } \\
\mathrm{A} \text { is vertically } \\
\text { integrated) }\end{array}$ & $\begin{array}{l}\text { Low } \\
\text { (cosy oligopoly) }\end{array}$ & \\
\hline & + & + & + & + & + & +++++ \\
\hline B & $\begin{array}{l}\text { Quite high } \\
\text { steep cost of } \\
\text { entry but cheap } \\
\text { imports }\end{array}$ & $\begin{array}{l}\text { High One major } \\
\text { buyer, state } \\
\text { telephone } \\
\text { company }\end{array}$ & Low & Low & $\begin{array}{l}\text { High Intense and } \\
\text { fierce international } \\
\text { competition }\end{array}$ & \\
\hline & - & -- & + & + & -- & --- \\
\hline \multirow[t]{2}{*}{$\mathrm{C}$} & $\begin{array}{l}\text { Quite high } \\
\text { entry barriers } \\
\text { exist, but other } \\
\text { MNCs are } \\
\text { active }\end{array}$ & $\begin{array}{l}\text { Quite high, large } \\
\text { buyers, such as } \\
\text { other water } \\
\text { companies, have } \\
\text { market power }\end{array}$ & Low & Low & $\begin{array}{l}\text { Quite high rising } \\
\text { competition as } \\
\text { foreign specialist } \\
\text { firms arrive }\end{array}$ & \\
\hline & - & - & + & + & - & - \\
\hline \multirow[t]{2}{*}{$\mathrm{D}$} & $\begin{array}{l}\text { Quite high } \\
\text { entry barriers } \\
\text { exist, other } \\
\text { MNCs have } \\
\text { arrived }\end{array}$ & $\begin{array}{l}\text { Quite high, large } \\
\text { buyers, such as } \\
\text { oil refineries, } \\
\text { have market } \\
\text { power }\end{array}$ & Low & Low & $\begin{array}{l}\text { Quiet high } \\
\text { increasing in } \\
\text { intensity as other } \\
\text { East German firms } \\
\text { modernise }\end{array}$ & \\
\hline & - & - & + & + & - & - \\
\hline \multirow[t]{2}{*}{$\mathrm{E}$} & Low & $\begin{array}{l}\text { Low diverse } \\
\text { customer base }\end{array}$ & $\begin{array}{l}\text { High } \\
\text { switch to } \\
\text { other } \\
\text { protein } \\
\text { sources }\end{array}$ & Low & $\begin{array}{l}\text { Critically high BSE } \\
\text { crisis decimated } \\
\text { demand }\end{array}$ & \\
\hline & + & + & -- & + & --- & -- \\
\hline $\mathrm{F}$ & Low & $\begin{array}{l}\text { Quite high large } \\
\text { oil refinery } \\
\text { buying power }\end{array}$ & Low & $\begin{array}{l}\text { Low Company } \mathrm{F} \\
\text { is vertically } \\
\text { integrated }\end{array}$ & $\begin{array}{l}\text { Low heavy speciality } \\
\text { product }\end{array}$ & \\
\hline & + & - & + & + & + & +++ \\
\hline
\end{tabular}

i Points are allocated as follows: Low=+; Quite High=-; High=-- ; Critically High=--- .

ii Results here are obtained by adding the pluses and minuses in the row. 
Table 5. Corporate entrepreneurship, predicted success 1996 and actual success 2001

\begin{tabular}{|c|c|c|c|c|}
\hline $\begin{array}{l}1 \\
\text { Company }\end{array}$ & $\begin{array}{l}2 \\
\text { Degree of corporate } \\
\text { entrepreneurship } \\
\text { Column 6, Table } 3\end{array}$ & $\begin{array}{l}3 \\
\text { Type of business } \\
\text { environment }+ \\
\text { or }- \\
\text { Col. 7, Table } 4\end{array}$ & $\begin{array}{l}4 \\
\text { Our Prediction of } \\
\text { Success in } 1996^{i}\end{array}$ & $\begin{array}{l}5 \\
\text { September } 2001 \\
\text { Success or failure }\end{array}$ \\
\hline A (US) & Medium & +++++ & Predicted success. & $\begin{array}{l}\text { Limited success: } \\
\text { One of the three original } \\
\text { owners divests. } \\
\text { Business continues to } \\
\text { prosper. }\end{array}$ \\
\hline $\mathrm{B}(\mathrm{UK})$ & Medium & --- & $\begin{array}{l}\text { Predicted uncertain } \\
\text { future: } \\
\text { Competition between } \\
\text { corporate } \\
\text { entrepreneurship and } \\
\text { environment. }\end{array}$ & $\begin{array}{l}\text { Failure: } \\
\text { Original owner divests. } \\
\text { New foreign owner, but } \\
\text { business continues to shrink } \\
\text { in size. }\end{array}$ \\
\hline C (Sweden) & High & - & Predicted success. & $\begin{array}{l}\text { Success: } \\
\text { Continued ownership } \\
\text { Business holds position in } \\
\text { market. }\end{array}$ \\
\hline $\mathrm{D}(\mathrm{UK})$ & High & - & Predicted success & $\begin{array}{l}\text { Success: } \\
\text { Continued ownership } \\
\text { Business holds position in } \\
\text { market. }\end{array}$ \\
\hline $\mathrm{E}(\mathrm{UK})$ & Low & -- & Predicted failure. & $\begin{array}{l}\text { Failure: } \\
\text { Original owner divests. } \\
\text { Management buyout, business } \\
\text { continues to exist but } \\
\text { exposed to potential spread } \\
\text { of agricultural epidemics. }\end{array}$ \\
\hline F (US) & Low & +++ & Predicted failure. & $\begin{array}{l}\text { Failure: } \\
\text { Original owner divests. } \\
\text { New foreign owner, but } \\
\text { business undergoes sustained } \\
\text { reduction in size. }\end{array}$ \\
\hline
\end{tabular}

${ }^{\mathrm{i}}$ This prediction of success or failure was made based upon the levels of corporate entrepreneurship present in 1996. High levels of corporate entrepreneurship in 1996 generated a prediction of survival, while low levels led to a prediction of failure. Where levels of corporate entrepreneurship were medium survival was predicted based upon the positive or negative state of the business environment.

predictions. We expected those firms having high levels of corporate entrepreneurship, to be likely long-term successes.

\section{Looking forward}

\section{The predicted impact of corporate entrepreneurship on} success

High combinations of the factors promoting corporate entrepreneurship means that even in the face of a slightly hostile 
environment, companies $\mathrm{C}$ and $\mathrm{D}$ should prosper and survive. Company A has a medium level of corporate entrepreneurship, which combined with a quasi-monopoly environment means that it too was predicted to survive. The future survival of Company B was predicted to be uncertain given the hostility of its environment coupled with only medium levels of corporate entrepreneurship. Given their low levels of corporate entrepreneurship companies $\mathrm{E}$ and $\mathrm{F}$ were predicted in 1996 to fail in the long term. Failure was predicted irrespective of environmental conditions, be they positive (Company F) or negative (Company E). Shortly after the end of the initial data collection period in 1996 Company F failed and was divested by its US owner. Its very low levels of corporate entrepreneurship limited its ability to expand, thus placing pressure on headcount in direct opposition to the goals of its minority shareholder the THA. The position became untenable and the firm was returned to the THA. Company E survived the BSE crisis, though this weakened it considerably. This crisis did not, however, trigger an innovative response through corporate entrepreneurial activities.

\section{Early impact of corporate entrepreneurship}

We have argued earlier that a consequence of a positive corporate entrepreneurship environment should be the creation of new capabilities. At the end of data analysis in 1997, some of these firms had high and medium levels of corporate entrepreneurship as we summarised in Table 3. We might, therefore, expect that the process of capability creation had already begun. What are then capabilities? Put simply, organisational capabilities are processes and routines that co-ordinate the firm's resources (such as human resources, capital equipment and market intelligence) into complex resource networks that efficiently and effectively develop, produce and deliver products and services to the market. $^{34}$

In 1997 data on the six cases gave an indication that new capabilities were appearing in the more successfully integrated companies $(\mathrm{C}$ and $\mathrm{D})$. The opposite was true in Company $\mathrm{E}$ and Company F, the unsuccessful contrast case. The focus of our analysis was upon the acquired firm, thus we focus upon new capabilities within East German acquisitions, not the international owner. Emergence of new capabilities within the acquired firms was identified through our interviews with East German managers and employees. In our discussion below we provide quotations from these interviews to support their claims.

In Company D a capability of customer-driven management had to be transposed from the western firm and integrated with a production-dominated view of the old East German organisation. This process of transposition and ultimate integration, or corporate entrepreneurship, was facilitated by a well-managed integration of the different company cultures. An interviewee in Company D expressed this transformation from production orientation to a customer-driven approach as follows: 
"Out of the former continuously filled order book grew a behavioural pattern of the planner. The planner was formerly at the centre not the customer. Now the picture has turned around 180 degrees, now the customer is king."

Company C made great efforts to devolve decision-making to lower levels in the organisation. Its managing director stated:

"Today we have a lower level of management who have the instruments at their control to make things happen, allowing me less deep involvement in projects and more opportunity to affect outside factors."

However, just making an organisational change does not guarantee immediate success, especially in an atmosphere where historically decisions were always pushed upwards. Clearly new capabilities are not created overnight. The managing director continues:

"Its not too easy to convert people to accept more responsibility, this is currently a hot topic, which the new organisation structure makes very visible."

The positive corporate entrepreneurship and new capabilities experienced in companies D and C contrasts with the experience of Company F. According to the western managing director of Company F, for the eastern acquisition to be successful it was necessary to create a new capability, namely responsive $R \& D$, which both existed in and was a key source of success in the western firm. However, this capability was not successfully transposed or integrated across the two firms. An interviewee explained the state of $\mathrm{R} \& \mathrm{D}$ in Company $\mathrm{F}$ prior to acquisition as follows:

"Whereas in most western companies, you would get monthly reports against goals and objectives for R\&D projects, and/or you would have periodic communications, meetings. They never did any of this. You would never see a report and it would just kind of disappear and hopefully one day they would come and say: 'well we think we have solved the problem and we are ready to talk to you about it'. But along the way they would never give you a status report."

Company $\mathrm{F}$ attempted to transpose a capability of responsiveness in a unidirectional manner. It did not encourage participation by the eastern employees in the development and adoption of an R\&D responsive capability. Efforts to integrate the differing company cultures in general, and $\mathrm{R} \& \mathrm{D}$ in particular were poorly managed. This ultimately resulted in a rejection of cross-firm knowledge and hence capability transfer and integration of R\&D. 


\section{1 survival: interactions between corporate entrepreneurship and environmental turbulence}

As we can see from Table 5, not all the firms continued to prosper by 2001. Companies C and D survived as predicted and were not divested by their original foreign owners. Company A survived but lost one of the three original foreign purchasers therefore we classify it as only a limited successful acquisition. Companies $\mathrm{E}$ and $\mathrm{F}$ were divested as predicted and while Company $\mathrm{E}$ continues to survive as an independent buy-out its future is uncertain. Company $\mathrm{F}$ was divested and having been acquired by a new foreign owner has undergone a sustained reduction in size, thus as both an acquisition and a business it has failed. Company B was divested to a new foreign owner thus as an acquisition it too failed, but as a business it continues to decline in size at the same pace as the market in which it operates.

As predicted firms with high levels of corporate entrepreneurship both survived and were retained within the portfolio of their original foreign acquirers. This occurred despite the negative business environment in which they operated. As we can see companies $\mathrm{C}$ and $\mathrm{D}$ were both considered to have an internal environment in which all the key features of corporate entrepreneurship were present, though slack resources were diminishing rapidly towards the end of our study in Company D. The corporate entrepreneurship of these firms has ensured sufficient internal transformation to survive but not to capture large increases in market share.

Survival of firms with a medium level of corporate entrepreneurship was very much influenced by environmental conditions. The key gaps in Company A and B's corporate entrepreneurship were the lack of a shared language and low levels of ambition. In these firms environmental turbulence played an important moderating influence between level of corporate entrepreneurship and survival. Company A had a medium level of success as one of its three foreign owners did divest its share. Company A had low ambition, but was situated in a monopoly market. The removal of that monopoly post-1996 may have activated a survival instinct triggering initiation of corporate entrepreneurial activities by filling two key gaps, namely giving it an ambition and forcing a shared language to be developed.

The original foreign owner (which went bankrupt) divested Company B prompting our classification as a failure. Company B was acquired by another foreign firm, however by 2001 it was facing negative growth in line with its market. Company B faced a more hostile environment than Company A and also a lower level of corporate entrepreneurship. For Company A team orientation was feasible if a shared language could be developed, as information hoarding was not a problem. Company B, however, lacked any team orientation: teams were both unwilling to share insights (information hoarding) and unable to do so (due to the lack of a shared language). Thus a marginally lower level 
Environmental

conditions have an

important moderating

effect of corporate entrepreneurship in Company B, combined with a considerably more negative business environment led to its failure. We can see that environmental conditions have an important moderating effect on the role of corporate entrepreneurship in influencing the survival of an acquisition.

Companies with low levels of corporate entrepreneurship were predicted to fail. In line with this prediction soon after 1996 Company $\mathrm{F}$ failed, despite being in the second most positive environment of the six firms. Company $\mathrm{E}$ was divested by its original British owner and is thus classified as a failure. Company E continues to exist as an independent entity having being bought out by management, however, the risk of business failure remains very high. Should further agricultural epidemics such as foot and mouth disease (FMD) spread across the EU in a similar pattern to the BSE crisis of the 1990s then Company E is poorly placed to survive another environmental shock because of its lack of corporate entrepreneurship.

Company E, as a green-field expansion, had no supply of organisational slack. Company $\mathrm{F}$ had slack resources but was not dynamically managing these resources through redeployment or encouraging employees to use slack time to engage in innovative experimentation. Neither company had developed a learning capability. In both firms there was a rejection of the cultural value of the eastern and western firm's differing approaches, leading to rigidity in mindsets of respective western and eastern staff towards each other. Neither group sought to learn from the diverse experiences of the other. Western management sought to dominate over the eastern, while the eastern staff engaged in passive resistance and avoidance of implementation of new business practices promoted by the western owners.

Given the lack of dynamic slack resources and the rejection of learning from diversity of each group it is unsurprising that in both firms there was not a culture that promoted curiosity and innovation as expressed through experimentation. Experiments would have been viewed as threatening by the East German staff. Experimental failure would not have been viewed as a part of the process of learning, but rather as a danger for an individual to be exposed to the floodlights of personal failure. Considering the above features it comes as no surprise that companies $\mathrm{E}$ and $F$ had an environment of fear and conservatism, not one of ambition.

\section{Managerial implications}

During the 1990s the concepts of organisational learning and knowledge management, which had been popularised by Argyris and Schon amongst others in the 1970s, increasingly competed with concepts such as corporate entrepreneurship for management attention..$^{35}$ It should be noted, however, that the two concepts are complementary, as knowledge creation and learning are central aspects of corporate entrepreneurship. ${ }^{36}$ It is our contention that discussing corporate entrepreneurship is not a retro- 
grade step. On the contrary it complements and co-exists with the learning organisation. Managers operating at the turn of the 21 st century are probably more familiar with the learning organisation than corporate entrepreneurship. We hope we have reiterated the importance of corporate entrepreneurship and by way of the two questions discussed below wish to convince managers of the practicality of corporate entrepreneurship.

\section{Who is able to influence the key constituents?}

The above question seems very superficial. Its obvious answer being - the management of the M\&As. However, a little deeper reflection is rewarded with the follow-on question of whether corporate entrepreneurship is a one-way issue, i.e. acquirer dependent? Certainly each of the constituents can be and were influenced by the incoming and/or existing management. Therefore, a case can be made for a purely acquirer-driven integration process. Given that the western acquirer had the benefits of financial clout and management expertise in a market-driven firm, it would not be surprising to see knowledge transfer being a oneway process, an eastwards one. However, our research showed that this interpretation is too simplistic. Incoming management in companies A, B, E and F failed to develop a shared language and hence hindered the transfer of knowledge. On the other hand, the acquired firms turned out not to be helpless victims of takeover by western firms in the wake of the collapse of the Berlin Wall. Companies C and D, with eastern stockholding, had legal countervailing powers in the boardroom to enable their voices to be heard. Company F showed the other extreme, where the eastern employees refused the western knowledge transfer in certain areas and gave up trying to integrate their expertise with the western firm.

In summary, the initiators of corporate entrepreneurship tend to be the acquirers but they can spoil the transfer of knowledge by neglecting the constituents of corporate entrepreneurship. In a few cases, the acquired company employees inhibited corporate entrepreneurship and in all cases, for corporate entrepreneurship to take place, their acceptance and agreement was necessary. The acquired have the ability to influence information hoarding and shared language dependent on the level of organisational slack. By controlling their end of the involvement with the constituents of corporate entrepreneurship, the acquired firm's management and employees can either get their message across to a willing partner acquirer, or they can attempt to champion their views, even in the face of a less open-minded acquirer.

\section{How can managers enact or nurture corporate entrepreneurship after takeover?}

This question can be answered by reference to our successful contrast M\&As, Company D. Here we see the successful integration achieved through eastern co-ownership, mixed with a bilingual top management and realistic expectations, on both sides, of where the firm was going. Given this strong basis, the 
first two constituents of corporate entrepreneurship (learning capability and team orientation) were satisfied. Organisational slack, although being reduced, was used to encourage information exchange as opposed to hoarding and transfer of resources to experimental new fields. This strong managerial concentration, on doing the integration correctly in the postacquisition phase, paid dividends, at least in the short run. Company D was successfully riding out the transformation to a market-driven company in an increasingly hostile environment. A benign environment can provide space for a firm to survive. Company A, was also successful in the short-term but here the success started from an attractive protected market, not from internally leveraged resources.

There are advantages in conducting research in extreme situations, in this case M\&As involving moribund ex-combines in reforming East Germany. One advantage is that the marriages are between two unequal partners. We have argued that even in conditions of revolutionary change and uncertainty that managers can influence and overcome the adverse environment through the fostering of corporate entrepreneurship. Our research gives instances of successful (and unsuccessful) intervention and indicates that corporate entrepreneurship plays a role in successful intervention.

Intelligent intervention by managers can bring about postacquisition success, via integrating the highlighted variables necessary to achieve corporate entrepreneurship. According to the model we have proposed, M\&As which survive through the short-term will succeed in the long-term if they have corporate entrepreneurship or use a protected market as an opportunity to change and address their internal constituents of corporate entrepreneurship. Attention to corporate entrepreneurship can keep an M\&A viable, helping to keep failure at bay. On the other hand, firms that neglect the constituents of corporate entrepreneurship will suffer the same fate as Company F, which, despite a benign business environment, failed.

\section{Conclusions}

This paper makes two important contributions to the literature. The first is to link corporate entrepreneurship to post-acquisition success. There are many examples in the literature of the relevance of corporate entrepreneurship to the renewal of mature organisations and the creation of new, innovative businesses within large firms. The role of corporate entrepreneurship in post-acquisition integration and survival has received little attention. This paper seeks to partially fill this gap. We have argued that fostering an environment of corporate entrepreneurship may play an important role in the long-term success of an acquisition. The case studies are not proof of a causal relationship between corporate entrepreneurship and acquisition success, 
however, the data analysis does suggest that such a relationship may well exist. Such a relationship would have important implications for the literature on both corporate entrepreneurship and post-acquisition integration.

Second, this paper takes up the recent call of scholars for studies to take account of time. ${ }^{37}$ This research is not ethnographic, however, it is longitudinal. We not only make predictions of the likely impact of corporate entrepreneurship on the success of an acquisition, but return after a considerable time to observe the long-term survival of these firms. We collected data real-time in 1995-1996, gaining a contemporary insight into the state of corporate entrepreneurship inside each of the six East German firms, we then waited for a seven-year period to observe the longterm survival of these firms. We would suggest that this is both unusual and important. It is unusual in that few researchers have the institutional support to wait seven years to assess the outcome of a research project. It is important because too often historical case study research can drift into posthoc rationalisation, where predictions and observation of outcomes are made at the same point in time, thus prediction neatly matches outcome. We avoid this trap by taking cognisance of the time involved in organisational research through separating data collection, analysis and observation of longer-term outcomes.

\section{Appendix A. Measures and methods}

\section{Measurement of surrogates}

As this was qualitative research, for all the surrogates in-depth interviews were transcribed and subject to a content analysis. The assessment of each of the factors was based more on a subjective, as opposed to mathematical evaluation of the contents. This means that there is an element of self-selection by the interviewees in measuring the importance of any particular variable. We find this consistent with the qualitative approach of allowing the subject to surface the importance of the various factors. However, the assessments as shown in Table 3, reflect the consolidation of the interviewee answers by the researchers.

1 Diverse perspectives. These were measured as a continuum from no integration of diverse perspectives to the presence and integration of diverse perspectives.

2 Team orientation.

(a) Lack of hoarding was assessed on a continuum from no freedom of exchange to free exchange of information.

(b) Shared language means the existence of a shared technical and managerial language enabling cross-functional communication and communication between East German and foreign management. Here the measure is a dichotomous yes/no assessment. 
We wish to express our appreciation to the editor of $L R P$, Charles Baden-Fuller, for his guidance and patience and also to two anonymous reviewers. This paper has also benefited from the comments of Madeleine Bateman, Dr Carla Millar, Dr Bobbe Pye, Dr Paul Raimond and Professor Frans van den Bosch.
3 Experimentation.

(a) Slack resources available for experiments. Slack resources were represented on a continuum from no slack present to much slack present in the system. Questions designed to measure slack were based on the format suggested by Bourgeois. ${ }^{38}$

(b) Culture supportive of experimentation: a continuum from active opposition to experimentation with current business practices to active support of experimentation by employees and management.

4 Aspirations. Here questions were only addressed to higherlevel managers. The questions probed whether new areas of sales, both geographical or product based, were being explored. The answers were consolidated on a continuum from low (no, or few new areas) to high (many new areas).

\section{Measurement of success/failure of M\&As}

We have defined survival as when the East German firm remains within the portfolio of the original foreign acquirer up to 2001 and use this as our metric of success. We argue that in this sample of firms, divestment was a signal of failure in creating new wealth in the acquired firm, not a signal of success. Where the acquirer fails to create new wealth in the acquired firm it recognises that it is not the best owner of the firm and hence disposes of the East German unit. All the firms were subsidiaries and their financial position was hidden in consolidated accounts in a foreign country making an accounting definition of success impossible. Obviously over the long-term, firms can only survive if they make a profit, so there is a temporal link between survival and profit. Therefore when reviewing the link between corporate entrepreneurship and success, recognition should be given to the internal and external environments and a differentiation made between the short-term and long-term. Thus we returned to the sample in 2001 to see if the firms had survived and whether the original acquirer had divested or retained the East German firm.

\section{References}

1. C. Hampden-Turner, Charting the Corporate Mind, Free Press, New York (1990).

2. S. Kaplan and M. Weisbach, "The success of acquisitions evidence from divestitures", Journal of Finance, 9(2), 107-138 (1992). This paper reported that $44 \%$ of acquisitions were subsequently divested. Divestitures on average experienced an $11 \%$ reduction in sale price versus initial purchase price when compared with a similar investment in the S\&P 500. Thus divestitures were sold at below their initial cost.

3. P. C. Haspeslagh and D. B. Jemison, "Acquisitions-myths and reality", Sloan Management Review, Winter, 53-58 (1987). 
4. W. D. Guth and A. Ginsberg, "Guest Editors' introduction: corporate entrepreneurship", Strategic Management Journal, 11, 5-15 (1990).

5. S. Zahra, A. Nielsen and W. Bogner, "Corporate entrepreneurship knowledge and competence development", Entrepreneurship Theory and Practice, 23(3), 169-189 (1999).

6. H. Barrett and A. Weinstein, "The effect of market orientation and organisational flexibility on corporate entrepreneurship", Entrepreneurship Theory and Practice, 23(1), 57-70 (1998).

7. C. Baden-Fuller and J. Stopford, "Creating corporate entrepreneurship", Strategic Management Journal, 15(7), 521-536 (1994). (We argue that this paper offers a solid basis upon which to identify the key constituents of corporate entrepreneurship not only because this was its central theme, but also because of its acceptance as an important work on corporate entrepreneurship within the academic community. According to the Social Citations Index the article has been cited by 22 other peer-reviewed articles, including seven papers in the leading entrepreneurship journal Journal of Business Venturing. It has also been cited by studies published on the topic in other leading journals such as Long Range Planning, the Strategic Management Journal, the Academy of Management Journal, and Organisation Science, in addition to scholarly books).

8. M. Porter, "From competitive advantage to corporate strategy", Harvard Business Review, May-June, 43-59 (1987)(see also Ref. [2]).

9. R. Grant, "Towards a knowledge based theory of the firm", Strategic Management Journal, 17, 109-122 (1996). J. March, "Exploration and exploitation in organisational learning", Organisational Science, 2(1), 71-87 (1991).

10. I. Nonaka, R. Toyama and N. Konno, "SECI Ba and leadership. A unified model of dynamic knowledge creation", Long Range Planning, 33(1), 5-34 (2000).

11. G. Jones and J. George, "The experience and evolution of trust: implications for co-operation and teamwork", Academy of Management Review, 23(3), 531-546 (1998).

12. G. Huber, "Organisational learning: the contributing processes and the literatures", Organisational Science, 2(1), 88115 (1991).

13. M. Hitt, R. Nixon, R. Hoskisson and R. Kochlar, "Corporate entrepreneurship and cross-functional fertilization: activation, process and disintegration of a new product design team", Entrepreneurship Theory and Practice, 23(3), 145167 (1999).

14. Baden-Fuller and Stopford, op. cit.

15. For an overview of the variety of definitions of corporate entrepreneurship in the literature the reader is referred to: P. Sharma, J. Chrisman, "Toward a reconciliation of the definitional issues in the field of corporate 
entrepreneurship", Entrepreneurship Theory and Practice, 23(3), 11-27 (1999).

16. C. Baden-Fuller and J. Stopford, Rejuvenating the Mature Business, Harvard Business School Press, Boston (1994).

17. Sharma and Curisman, op. cit.

18. March, op. cit.

19. Grant, op. cit.

20. K. Carley, "Organisational learning and personnel turnover", Organisational Science, 3(1), 20-46 (1992). P. McNamara, The Antagonistic Nature of Knowledge Management, Academy of Management Conference, Organisation and Management Theory Division (2000).

21. J. P. Walsh, "Top management turnover following mergers and acquisitions", Strategic Management Journal, 9(2), 173183 (1988).

22. Interview quotations are taken from transcripts of taperecorded interviews, which were undertaken and translated from German by the research team.

23. A. Romme, "A note on the hierarchy-team debate", Strategic Management Journal, 17(5), 411-417 (1996).

24. B. Kirkman, R. Jones and D. Shapiro, "Why do employees resist teams? Examining the resistance barrier to work team effectiveness", The International Journal of Conflict Management, 11(1), 74-92 (2000).

25. G. Jones and J. George, "The experience and evolution of trust: implications for co-operation and teamwork", Academy of Management Review, 23(3), 531-546 (1998).

26. Jones and George, op. cit.

27. Hitt et al., op. cit.

28. Zahra, Nielsen and Bogner, op. cit.

29. N. Nohria and R. Gulati, "Is slack good or bad for innovation?", Academy of Management Journal, 39(5), 12451264 (1996).

30. I. Nonaka and H. Takeuchi, The Knowledge Creating Company, Oxford University Press, Oxford (1995).

31. N. Nohria and R. Gulati, "What is the optimal amount of organisational slack? A study of the relationship between slack and innovation in multinational firm", European Management Journal, 15(6), 603-611 (1997).

32. G. Hamel and C. Prahalad, "Strategy as stretch and leverage", Harvard Business Review, March-April, 75-84 (1993).

33. M. E. Porter, Competitive Strategy, Free Press, New York (1980).

34. R. Amit and P. Schoemaker, "Strategy assets and organisational rent", Strategic Management Journal, 14(1), 33-46 (1993).

35. C. Argyris and D. Schon, Organisational Learning: A Theory of Action Perspective, Addison-Wesley, Reading, MA (1978). D. Leonard-Barton, Wellsprings of Knowledge: Building and Sustaining the Sources of Innovation, Harvard Business School Press, Boston (1995). 
36. Zhara, Nielsen and Bogner, op cit. Baden-Fuller and Stopford, op. cit.

37. A. Pettigrew, R. Woodman and K. Cameron, "Studying organisational change and development: challenges for future research", Academy of Management Journal, 44(4), 697-713 (2001).

38. J. Bourgeois, "On the measurement of organisational slack", Academy of Management Review, 6(1), 29-39 (1981). 